\title{
Haemodynamic and plasma vasopressin responses during high-dose fentanyl or sufentanil anaesthesia
}

A. J. Boulton MB, CH B FRCPC, N. Wilson, PHD, K. W. Turnbull MD FRCPC, R. W. Yip MD FRCPC
This study compared the haemodynamic and arginine vasopressin responses of patients to fentanyl or sufentanil anaesthesia for coronary artery bypass surgery. Fourteen normotensive patients with normal left ventricular function were studied. Patients were induced with fentanyl $(N=7) 37.5 \mu \mathrm{g} \cdot \mathrm{kg}^{-1}$ or sufentanil $(N=7)$ $7.5 \mu \mathrm{g} \cdot \mathrm{kg}^{-1}$ by intravenous infusion over three minutes. Clinically important chest wall rigidity, bradycardia and recall of intraoperative events did not occur. All of the fentanyl patients became hypertensive after induction and five required vasodilator therapy since they did not respond to boluses of fentanyl $\left(12.5 \mu \mathrm{g} \cdot \mathrm{kg}^{-1}\right)$. Two of these five patients had S-T depression greater than $1 \mathrm{~mm}$. Five patients in the sufentanil group became hypertensive after induction. Four of these patients responded to additional sufentanil ( $\left.3.75 \mu \mathrm{g} \cdot \mathrm{kg}^{-1}\right)$ while one required vasodilator therapy for concomitant S-T depression. Sufentanil attenuated the increase of arginine vasopressin during cardiopulmonary bypass. Levels of arginine vasopressin in the fentanyl group were significantly

\section{Key words}

BLOOD PRESSURE: drug effects; ANALGESICS: fentanyl, sufentanil; COMPLICATIONS: hypertension; HORMONES: arginine vasopressin.

From the Department of Anaesthesia and the Department of Physiology (Dr. Wilson), University of British Columbia, Vancouver, British Columbia.

Address correspondence to: Dr. K. W. Turnbull, Department of Anaesthesia, Vancouver General Hospital, Room 3200, 910 West 10th Avenue, Vancouver, B.C. V5Z 4E3. higher than those of the sufentanil group during bypass. Levels of AVP after bypass were higher in the sufentanil group.

The incidence of hypertension was similar in both groups. The hypertension was more easily treated with sufentanil but concomitant vasodilators (nitroglycerine) were required in both pasient groups. Neither fentanyl in doses up to $128 \pm 8.7 \mu \mathrm{g} \cdot \mathrm{kg}^{-1}$ nor sufentanil in doses up to $23 \pm 1.4 \mu \mathrm{g} \cdot \mathrm{kg}^{-1}$ can be used as sole agents for anaesthesia in adult coronary artery bypass patients with good ventricular function when induction times are three minutes and bolus top-up doses are used.

Sufentanil citrate is a new synthetic opiate analgesic' which is about 4500 times as potent as morphine and five to ten times as potent as fentanyl. ${ }^{2}$ Sufentanil has a much higher therapeutic ratio, faster onset of action and shorter terminal elimination half-life than fentanyl. ${ }^{3}$ These characteristics have led to the use of sufentanil as the principal anaesthetic agent in aorto-coronary bypass operations. ${ }^{4}$ Sufentanil has been thought to provide similar haemodynamic stability in equipotent doses to that of fentanyl. Current anaesthetic techniques for coronary artery bypass surgery strive for amelioration or elimination of significant stress responses as reflected by fluctuations in plasma catecholamines, plasma vasopressin and haemodynamic stability. Attenuation of such stress responses is felt to lessen the adverse effects of vascular smooth muscle constriction and minimize changes in myocardial oxygen demands. Previous work from this centre has shown fentanyl has little effect on plasma vasopressin levels during bypass. 
TABLE I Demographic data

\begin{tabular}{lcc}
\hline & \multicolumn{2}{c}{ Group } \\
\cline { 2 - 3 } & Fentanyl & Sufentanil \\
\hline Number of patients & 7 & 7 \\
Wcight $(\mathrm{kg})$ & $79 \pm 14$ & $79 \pm 10$ \\
Height (cm) & $170 \pm 7$ & $171 \pm 7$ \\
Age (years) & $58 \pm 8$ & $58 \pm 9$ \\
\hline
\end{tabular}

$(\mathrm{M} \pm \mathrm{SD})$.

Haemodynamic stability during tracheal intubation was maintained. Sternotomy resulted in significant haemodynamic instability. ${ }^{30}$ Haemodynamic variability was a characteristic of the high-dose fentanyl used $\left(50-100 \mu \mathrm{g} \cdot \mathrm{kg}^{-1}\right)$ in that study. The present study was done to evaluate the use of larger doses of fentanyl (in the range of $125 \mu \mathrm{g} \cdot \mathrm{kg}^{-1}$ ) and to compare this approach with the use of sufentanil (in the range of $25 \mu \mathrm{g} \cdot \mathrm{kg}^{-1}$ ) in a further effort to obtain haemodynamic stability. Vasopressin responses were assessed as a reflection of the physiological milieu of the patients.

\section{Methods}

Fourteen patients (age 44 to 68) scheduled for elective coronary artery bypass surgery were studied, after obtaining informed consent at a preoperative visit. The protocol was approved by both the University and the Hospital Human Research Committees. All the patients were ASA physical status Class III or IV scheduled to have first-time coronary artery bypass grafts.

Patients were selected with normal preoperative cardiovascular dynamics. All patients were normotensive and had adequate left ventricular function with left ventricular end diastolic pressures of $<20 \mathrm{mmHg}$ and ejection fractions $>0.5$. Patients were randomly assigned to the fentanyl and sufentail groups. Demographic and concurrent medication data are shown in Tables I and II.

Patients were premedicated with oral lorazepam $2 \mathrm{mg}$ and intramuscular morphine $0.15 \mathrm{mg} \cdot \mathrm{kg}^{-1}$ one hour preoperatively. Beta-adrenergic blocking agents, calcium channel blocking agents and nitrates were continued up to one to two hours prior to the time of surgery. Electrocardiograph monitoring leads $\left(V_{5}\right)$ were connected after the patients arrived in the operating room. Peripheral venous, central venous, radial artery and pulmonary artery cathe- ters were inserted under local anaesthesia. The Oximetric flow directed balloon-tipped thermodilution pulmonary artery catheter was inserted via the right internal or external jugular vein. Haemodynamic measurements and blood samples were then taken for control values.

An oesophageal temperature probe and urinary catheter were inserted after induction. Pancuronium $0.02 \mathrm{mg} \cdot \mathrm{kg}^{-1}$ was given intravenously and followed by three minutes of 100 per cent oxygen by face mask. This was followed by either sufentanil $7.5 \mu \mathrm{g} \cdot \mathrm{kg}^{-1}$ or fentanyl $37.5 \mu \mathrm{g} \cdot \mathrm{kg}^{-1}$ by intravenous infusion over three minutes. Ventilation was assisted manually, as necessary, with 100 per cent oxygen. Intubation was facilitated by the administration of succinylcholine $1.5 \mathrm{mg} \cdot \mathrm{kg}^{-1}$ intravenous ly. All patients were then mechanically ventilated with 100 per cent oxygen to maintain normocapnia $\left(\mathrm{PaCO}_{2} \quad 35-40 \mathrm{mmHg}\right)$. Pancuronium $0.08 \mathrm{mg} \cdot \mathrm{kg}^{-1}$ was given within 13 minutes of the start of the narcotic infusion. Muscle relaxation was maintained using $0.04 \mathrm{mg} \cdot \mathrm{kg}^{-1}$ increments of pancuronium every 45 to 60 minutes. Pancuronium $0.04 \mathrm{mg} \cdot \mathrm{kg}^{-1}$ was administered to all patients just prior to cardiopulmonary bypass. Sufentanil $3.75 \mu \mathrm{g} \cdot \mathrm{kg}^{-1}$ or fentanyl $18.75 \mu \mathrm{g} \cdot \mathrm{kg}^{-1}$ were given intravenously three minutes prior to skin incision and three minutes prior to sternotomy resulting in total pre-sternotomy doses of $15 \mu \mathrm{g} \cdot \mathrm{kg}^{-1}$ or $75 \mu \mathrm{g} \cdot \mathrm{kg}^{-1}$ for sufentanil and fentanyl respectively.

The criteria for hypertension were a rise in systolic blood pressure of at least 15 per cent above the control level or a mean blood pressure on cardiopulmonary bypass of more than $100 \mathrm{mmHg}$. Either of these events was treated with additional doses of $2.5 \mu \mathrm{g} \cdot \mathrm{kg}^{-1}$ of sufentanil or $12.5 \mu \mathrm{g} \cdot \mathrm{kg}^{-1}$ of fentanyl administered by bolus injection. Failure of two successive doses of narcotics to return the blood pressure to below these levels within five minutes resulted in the institution of vasodilator

TABLE II Concurrent medication

\begin{tabular}{lll}
\hline & \multicolumn{2}{l}{ Group } \\
\cline { 2 - 3 } & Fentanyl & Sufentanil \\
\hline Calcium channel blocking agents & 5 & 4 \\
Beta-adrenergic blocking agents & 4 & 2 \\
Nitrates & 7 & 5 \\
\hline
\end{tabular}


therapy using sodium nitroprusside or nitroglycerine infusions.

An Optiflo ${ }^{\circledR}$ II bubble oxygenator was primed with two litres of Plasmalyte ${ }^{\circledR}$ and patients were heparinized with 300 units $\mathrm{kg}^{-1}$ sodium heparin. Blood products were administered as necessary to maintain adequate filling pressures. Patients were cooled to $30^{\circ} \mathrm{C}$ during cardiopulmonary bypass and re-warmed to at least $37^{\circ} \mathrm{C}$ at its conclusion. All patients were electively ventilated overnight.

Heart rate, systolic, diastolic and mean blood pressures, right atrial pressure, pulmonary diastolic and capillary wedge pressures were recorded before induction $\left(\mathrm{T}_{1}\right)$, at the end of induction prior to intubation $\left(T_{2}\right)$, post-intubation $\left(T_{3}\right)$, pre-skin incision $\left(\mathrm{T}_{4}\right)$, post-skin incision $\left(\mathrm{T}_{5}\right)$, post-sternotomy $\left(\mathrm{T}_{6}\right)$, pre-bypass $\left(\mathrm{T}_{7}\right)$, end of bypass $\left(\mathrm{T}_{8}\right)$, postprotamine $\left(\mathbf{T}_{13}\right)$, post-sternal closure $\left(\mathbf{T}_{14}\right)$, and thirty minutes after arrival in the intensive care unit $\left(T_{15}\right)$. Cardiac output measurements were performed in triplicate at the same interval. Mean blood pressures were recorded on bypass at three $\left(\mathrm{T}_{8}\right), 15\left(\mathrm{~T}_{9}\right), 30\left(\mathrm{~T}_{10}\right), 60$ minutes $\left(\mathrm{T}_{11}\right)$ and just prior to coming off bypass $\left(\mathrm{T}_{12}\right)$. Blood and urine samples were collected at all the above times. Plasma arginine vasopressin (AVP), serum electrolytes, serum osmolality, plasma proteins, urine electolytes, urine osmolality and haematocrit were also measured at these times. Blood samples for AVP were also collected on the day prior to surgery $\left(\mathrm{T}_{0}\right)$. Cardiac index, systemic vascular resistance, pulmonary vascular resistance and left ventricular stroke work index were calculated for all nonbypass sampling times.

The blood samples for AVP assay were collected in EDTA tubes, placed on ice and the plasma separated by centrifuge within one hour. The plasma was stored at $-20^{\circ} \mathrm{C}$ until radioimmunoassay. The AVP was measured following extraction of plasma with organic solvents using a previously described RIA system. ${ }^{5}$ The AVP values were corrected for extraction losses.

All patients in this study were interviewed by one of the authors (A.B.) three days postoperatively for evaluation of intraoperative awareness, and adequacy of the anaesthetic technique. The patients were asked what the first thing was which they remembered after the start of their anaesthetic and how they rated their anaesthetic subjectively given the choice of good, satisfactory or bad.
TABLE III Incidence of hypertension

\begin{tabular}{lcccc}
\hline \multicolumn{3}{c}{ Group } \\
\cline { 2 - 5 } & $\begin{array}{l}\text { Fentanyl } \\
(N=7)\end{array}$ & $\begin{array}{l}\text { Sufentanil } \\
(N=7)\end{array}$ \\
\hline Hypertension prior to CPB & $7 / 7$ & $100 \%$ & $5 / 7$ & $71 \%$ \\
(\% requiring vasodilators) & $(5 / 7)$ & $(71 \%)$ & $(1 / 7)$ & $(14 \%)$ \\
Hypertension during CPB & $5 / 7$ & $71 \%$ & $7 / 7$ & $57 \%$ \\
(\% requiring vasodilators) & $(5 / 7)$ & $(71 \%)$ & $(3 / 7)$ & $(43 \%)$ \\
\hline
\end{tabular}

Descriptive statistics and independent "t-tests" between the sufentanil group $(\mathrm{N}=7)$ and the fentanyl group $(\mathrm{N}=7$ ) were performed by the Statistical Package for the Social Services (SPSS). Repeated measures analysis for comparisons with each group were performed using analysis of variance. Bonferoni multiple contrasts guaranteeing overall $\mathrm{p}<0.05$ were considered significant. Results are expressed as mean \pm standard error of the mean.

\section{Results}

The doses were $128 \pm 8.7 \mu \mathrm{g} \cdot \mathrm{kg}^{-1}$ (mean $\pm \mathrm{SE}$ ) of fentanyl and $23 \pm 1.4 \mu \mathrm{g} \cdot \mathrm{kg}^{-1}$ (mean $\pm \mathrm{SE}$ ) of sufentanil. The mean age, weight and height in the two groups were similar (Table I). Concurrent medication use was similar (Table II). There was no statistically significant difference between the fentanyl and sufentanil groups with respect to any of the measured or derived haemodynamic data, neither were there significant changes within the groups (Table III, IV, V, VI). Mean duration of bypass was $117 \pm 14$ minutes for the fentanyl groups and $118 \pm 12$ minutes for the sufentanil groups $(M \pm S E)$.

\section{Haemodyamic data - fentanyl group}

All patients became hypertensive following intubation, post-skin incision and/or post-sternotomy. Five of these patients required vasodilator therapy for control of blood pressure. Two of these patients exhibited S-T depression ( $>1 \mathrm{~mm}$ ) associated with hypertension, both of which responded to intravenous nitroglycerine infusion $\left(1 \mu \mathrm{g} \cdot \mathrm{kg}^{-1} \cdot \mathrm{min}^{-1}\right)$. Both of these patients subsequently moved, despite receiving $125 \mu \mathrm{g} \cdot \mathrm{kg}^{-1}$ of fentanyl. Isoflurane $(0.5$ per cent) was added to their anaesthetic regime. Five patients became hypertensive during bypass and all required vasodilator therapy. One patient be- 
TABLE IV Mean heart rate, systolic and mean blood pressure, pulmonary capillary wedge pressure and cardiac index for the sufentanil and fentanyl groups

\begin{tabular}{|c|c|c|c|c|c|c|c|c|c|}
\hline \multirow{3}{*}{$\begin{array}{l}\begin{array}{l}\text { Time } \\
\text { interval }\end{array} \\
\mathrm{HR}\end{array}$} & \multicolumn{2}{|r|}{$T$} & $T_{2}$ & \multicolumn{2}{|c|}{$T_{3}$} & $T_{4}$ & $T_{5}$ & $T_{6}$ & $T_{7}$ \\
\hline & $\mathrm{F}$ & $59 \pm 3$ & $58 \pm 3$ & & & $66 \pm 7$ & $60 \pm 3$ & $66 \pm 4$ & $66 \pm 5$ \\
\hline & $\mathbf{S}$ & $61 \pm 3$ & $63 \pm 3$ & & \pm 5 & $66 \pm 4$ & $64 \pm 3$ & $66 \pm 4$ & $70 \pm 5$ \\
\hline \multirow[t]{2}{*}{ SBP } & F & $150 \pm 4$ & \multirow{2}{*}{$\begin{array}{l}132 \pm 8 \\
134 \pm 9\end{array}$} & \multirow{2}{*}{\multicolumn{2}{|c|}{$\begin{array}{l}160 \pm 11 \\
139 \pm 10\end{array}$}} & $149 \pm 9$ & $155 \pm 11$ & $170 \pm 12$ & $130 \pm 7$ \\
\hline & $s$ & $137 \pm 5$ & & & & $136 \pm 7$ & $148 \pm 8$ & $159 \pm 8$ & $129 \pm 6$ \\
\hline \multirow[t]{2}{*}{ MBP } & $\mathrm{F}$ & $97 \pm 7$ & \multirow{2}{*}{$\begin{array}{l}86 \pm 8 \\
90 \pm 6\end{array}$} & \multirow{2}{*}{\multicolumn{2}{|c|}{$\begin{array}{r}104 \pm 9 \\
95 \pm 6\end{array}$}} & $97 \pm 8$ & $103 \pm 9$ & $112 \pm 9$ & $90 \pm 6$ \\
\hline & $\mathrm{s}$ & $91 \pm 2$ & & & & $92 \pm 4$ & $103 \pm 6$ & $112 \pm 5$ & $93 \pm 4$ \\
\hline \multirow[t]{2}{*}{ PCWP } & $F$ & $10 \pm 1$ & $13 \pm 3$ & \multicolumn{2}{|c|}{$14 \pm 1$} & $10 \pm 2$ & $12 \pm 2$ & $13 \pm 1$ & $9 \pm 1$ \\
\hline & $S$ & $10 \pm 1$ & $14 \pm 1$ & \multicolumn{2}{|c|}{$13 \pm 1$} & $12 \pm 1$ & $12 \pm 1$ & $12 \pm 1$ & $9 \pm 1$ \\
\hline \multirow[t]{2}{*}{$\mathrm{CI}$} & $\mathrm{F}$ & $2.8 \pm 0.1$ & $2.9 \pm 0.2$ & \multicolumn{2}{|c|}{$2.8 \pm 0.2$} & $3.0 \pm 0.3$ & $3.0 \pm 0.3$ & $3.0 \pm 0.5$ & $1.9 \pm 0.1$ \\
\hline & $S$ & $2.9 \pm 0.2$ & $2.6 \pm 0.2$ & \multicolumn{2}{|c|}{$2.9 \pm 0.3$} & $2.6 \pm 0.2$ & $2.6 \pm 0.2$ & $2.5 \pm 0.2$ & $2.0 \pm 0.2$ \\
\hline \multicolumn{10}{|l|}{ Time } \\
\hline interval & & $T_{8}$ & $T_{9}$ & $T_{10}$ & $T_{n}$ & $T_{2 z}$ & $T_{13}$ & $T_{14}$ & $T_{15}$ \\
\hline \multirow[t]{2}{*}{ HR } & $\mathrm{F}$ & & & & & & $90 \pm 6$ & $86 \pm 6$ & $81 \pm 6$ \\
\hline & $s$ & & & & & & $86 \pm 5$ & $88 \pm 5$ & $80 \pm 4$ \\
\hline \multirow[t]{2}{*}{ SBP } & $\mathrm{F}$ & & & & & & $118 \pm 6$ & $141 \pm 5$ & $127 \pm 9$ \\
\hline & $S$ & & & & & & $123 \pm 5$ & $134 \pm 8$ & $131 \pm 9$ \\
\hline \multirow[t]{2}{*}{ MBP } & $\mathrm{F}$ & $76 \pm 7$ & $73 \pm 8$ & $91 \pm 5$ & $77 \pm 6$ & $65 \pm 3$ & $78 \pm 4$ & $84 \pm 13$ & $89 \pm 6$ \\
\hline & 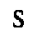 & $74 \pm 7$ & $83 \pm 6$ & $85 \pm 3$ & $84 \pm 3$ & $65 \pm 3$ & $90 \pm 4$ & $100 \pm 5$ & $90 \pm 5$ \\
\hline \multirow[t]{2}{*}{ PCWP } & $\mathrm{F}$ & & & & & & $17 \pm 1$ & $16 \pm 1$ & $16 \pm 1$ \\
\hline & $s$ & & & & & & $18 \pm 2$ & $17 \pm 1$ & $13 \pm 2$ \\
\hline \multirow[t]{2}{*}{$\mathrm{CI}$} & $\mathrm{F}$ & & & & & & $3.3 \pm 0.2$ & $2.6 \pm 0.2$ & $2.5 \pm 0.2$ \\
\hline & $\mathrm{s}$ & & & & & & $3.1 \pm 0.2$ & $2.4 \pm 0.2$ & $2.4 \pm 0.1$ \\
\hline
\end{tabular}

*p $<0.05$ mean error shown below mean values.

HR - beats/min. SBP, MBP, PCWP - mmHg. CI $-\mathrm{L} \cdot \mathrm{min}^{-1} \mathrm{~m}^{-2}$. F - fentanyl. $S-$ sufentanil. $T_{1}-$ control. $T_{2}-$ induction. $T_{3}-$ post induction. $T_{4}$ - pre-skin. $T_{5}$ - post skin. $T_{6}$ - post sternotomy. $T_{7}-$ pre-bypass. $T_{8}, 9,10,11-$ bypass $3,15,30,60$ minutes respectively. $T_{12}$ - end bypass. $T_{13}-$ post protamine. $T_{14}$ - post sternal closure. $T_{15}-$ PAR 30 minutes.

came severely hypotensive following induction (MAP $<65 \mathrm{mmHg}$ ) and two patients required inotropic support while coming off bypass.

Haemodyamic data - sufentanil group Five patients became hypertensive following intubation, post-skin incision and/or post-sternotomy but only one required vasodilator therapy. The other four patients responded well to additional ( 3.75 $\mu \mathrm{g} \cdot \mathrm{kg}^{-1}$ ) sufentanil boluses. One patient required more than $7.5 \mu \mathrm{g} \cdot \mathrm{kg}^{-1}$ of sufentanil to induce unconsciousness and he moved 15 minutes following sternotomy despite receiving $20 \mu \mathrm{g} \cdot \mathrm{kg}^{-1}$ sufentanil and pancuronium $\left(0.08 \mu \mathrm{g} \cdot \mathrm{kg}^{-1}\right)$ as previously noted. Isoflurane was added to his anaesthetic regime.

One patient developed S-T depression ( $>1 \mathrm{~mm}$ ) associated with hypertension 30 minutes after sternotomy. He was treated successfully with intravenous nitroglycerine $\left(1 \mu \mathrm{g} \cdot \mathrm{kg}^{-1} \cdot \mathrm{min}^{-1}\right)$. Four pa- 
TABLE V Mean left ventricular stroke work index and systemic vascular resistance for the sufentanil and fentanyl groups

\begin{tabular}{|c|c|c|c|c|c|c|c|c|}
\hline $\begin{array}{l}\text { Time } \\
\text { interval }\end{array}$ & & $T$ & $T_{2}$ & $T_{3}$ & $T_{4}$ & $T_{5}$ & $T_{5}$ & $T_{7}$ \\
\hline \multirow[t]{2}{*}{ LVSWI } & $\mathbf{F}$ & $59 \pm 5$ & $57 \pm 7$ & $59 \pm 7$ & $56 \pm 8$ & $66 \pm 8$ & $65 \pm 8$ & $31 \pm 2$ \\
\hline & $\mathbf{S}$ & $55 \pm 3$ & $49 \pm 7$ & $50 \pm 5$ & $45 \pm 4$ & $52 \pm 4$ & $54 \pm 4$ & $37 \pm 4$ \\
\hline \multirow[t]{2}{*}{ SVR } & $\mathbf{F}$ & $1426 \pm 134$ & $1203 \pm 141$ & $1488 \pm 143$ & $1413 \pm 206$ & $1403 \pm 168$ & $1673 \pm 262$ & $1935 \pm 242$ \\
\hline & $S$ & $1295 \pm 89$ & $1782 \pm 608$ & $1300 \pm 88$ & $1435 \pm 84$ & $1500 \pm 125$ & $1846 \pm 176$ & $1859 \pm 165$ \\
\hline $\begin{array}{l}\text { Time } \\
\text { interval }\end{array}$ & & $T_{s}$ & $T_{11} \quad T_{f 2}$ & $T_{i 3}$ & $T_{1 / 4}$ & $T_{15}$ & & \\
\hline \multirow[t]{2}{*}{ LVSWI } & $\mathrm{F}$ & & & $34 \pm 3$ & $32 \pm 7$ & $34 \pm 4$ & & \\
\hline & $\mathbf{S}$ & & & $38 \pm 3$ & $35 \pm 5$ & $37 \pm 3$ & & \\
\hline \multirow[t]{2}{*}{ SVR } & $\mathrm{F}$ & & & $871 \pm 55$ & $1304 \pm 292$ & $1307 \pm 143$ & & \\
\hline & $S$ & & & $1122 \pm 90$ & $1598 \pm 143$ & $1608 \pm 159$ & & \\
\hline
\end{tabular}

*p $<0.05$. Mean error shown below mean valucs.

LSVSWI - left ventricular stroke work index. SVR - systemic vascular resistance

tients developed hypertension during bypass. Three of these patients required vasodilator therapy for control of this hypertension. Three patients required inotropic support coming off bypass.

\section{Other results}

Plasma arginine vasopressin (AVP) remained at basal levels until the start of bypass. AVP levels then increased in both groups with that of the fentanyl group being significantly increased (Figure 1 - Table VI). All patients in the sufentanil groups had increased AVP levels post-bypass, and one patient had very high AVP levels post-bypass. This coincided with hypertension requiring vasodilators. The AVP values for this patient increased by 15 times on bypass and by 30 times in the PAR.

Three sufentanil patients and four fentanyl patients developed mild chest rigidity which did not compromise the anaesthetic. No patient remembered any aspect of the laryngoscopy, intubation or operation. The first event recalled by patients was awakening in the intensive care unit. All patients rated the anaesthetic as good.

Plasma protein levels on the day prior to surgery were $8.49 \pm 0.30 \mathrm{~g} \cdot \mathrm{dl}^{-1}(\mathrm{M} \pm \mathrm{SE})$ in the fentanyl and $8.05 \pm 0.11 \mathrm{~g} \cdot \mathrm{dl}^{-1}$ in the sufentanil patients. Plasma proteins decreased in all patients during bypass, reaching $3.85 \pm 0.19 \mathrm{~g} \cdot \mathrm{dl}^{-1}$ (fentanyl) and $3.99 \pm 0.17 \mathrm{~g} \cdot \mathrm{dl}^{-1}$ (sufentanil) at mid-bypass.
These levels persisted until the end of the bypass period. The plasma protein levels were $5.65 \pm$ $0.25 \mathrm{~g} \cdot \mathrm{dl}^{-1}$ (fentanyl) and $5.76 \pm 0.18 \mathrm{~g} \cdot \mathrm{dl}^{-1}$ (sufentanil) in the immediate postoperative period.

Haematocrit changes paralleled those for plasma proteins. The haematocrits were $42.0 \pm 1.0$ per cent (fentanyl) and $41.0 \pm 0.19$ per cent (sufentanil) on the day prior to surgery. The levels fell and remained low $(23.0 \pm 1.4$ per cent and $24.2 \pm 1.2$ per cent) during bypass. The haematocrit increased in the immediate postoperative period (to $34.9 \pm$ 1.7 per cent and to $34.6 \pm 1.6$ per cent).

The serum osmolality of all patients was within normal limits (275-295 mosm). The serum osmolality in the fentanyl patients during bypass (277.2 $\pm 3.3 \mathrm{mosm}$ ) was significantly different from the post-bypass value $(285.3 \pm 4.0 \mathrm{mosm})$. No significant changes were observed in serum sodium or free water clearance (Table VI) in either patient group. Osmolar clearance increased during bypass in the fentanyl patients and after bypass in the sufentanil patients (Table VI). Osmolar clearance changes were paralleled by changes in sodium clearance. Increases in plasma AVP in both groups of patients do not correspond to the times of increased osmolar clearance.

\section{Discussion}

The use of large doses of opiate analgesics as the 
TABLE VI Plasma vasopression (AVP) and renal clearance measurements

\begin{tabular}{|c|c|c|c|c|c|c|c|c|}
\hline & $T_{0}$ & $T_{1}$ & $T_{2}$ & $T_{3}$ & $T_{4}$ & $T_{s}$ & $T_{6}$ & $T_{7}$ \\
\hline \multicolumn{9}{|c|}{ Fentanyl $(n=7)$} \\
\hline AVP & 3.7 & 1.9 & 1.6 & 2.7 & 2.0 & 2.6 & 2.1 & 2.6 \\
\hline $\mathrm{pg} \cdot \mathrm{ml}^{-1}$ & \pm 1.2 & \pm 0.4 & \pm 0.7 & \pm 1.4 & \pm 0.7 & \pm 0.6 & \pm 1.6 & \pm 0.6 \\
\hline $\begin{array}{l}\mathrm{CH}_{2} \mathrm{O} \\
\mathrm{ml} \cdot \mathrm{min}^{-1}\end{array}$ & - & - & - & - & $\begin{array}{l}-0.79 \\
\pm 0.23\end{array}$ & $\begin{array}{l}-1.09 \\
\pm 0.55\end{array}$ & $\begin{array}{l}-0.72 \\
\pm 0.64\end{array}$ & $\begin{array}{l}-0.85 \\
\pm 0.39\end{array}$ \\
\hline $\mathrm{C}_{\text {Osm }}$ & - & - & - & - & $\begin{array}{l}1.35 \\
\pm 0.5\end{array}$ & $\begin{array}{l}2.00 \\
\pm 0.92\end{array}$ & $\begin{array}{l}2.50 \\
\pm 1.98\end{array}$ & $\begin{array}{l}2.02 \\
\pm 0.93\end{array}$ \\
\hline \multicolumn{9}{|c|}{ Sufentanil $(n=7)$} \\
\hline AVP & 2.0 & 4.3 & 3.7 & 2.9 & 2.7 & 3.0 & 2.4 & 2.7 \\
\hline $\mathrm{pg} \cdot \min ^{-1}$ & \pm 0.3 & \pm 1.4 & \pm 0.8 & \pm 0.7 & \pm 0.7 & \pm 0.5 & \pm 0.5 & \pm 0.4 \\
\hline $\begin{array}{l}\mathrm{CH}_{2} \mathrm{O} \\
\mathrm{ml} \cdot \mathrm{min}^{-1}\end{array}$ & - & - & - & - & $\begin{array}{l}-0.40 \\
\pm 0.20\end{array}$ & $\begin{array}{l}-0.60 \\
\pm 0.81\end{array}$ & $\begin{array}{l}-0.74 \\
\pm 0.42\end{array}$ & $\begin{array}{l}-0.05 \\
\pm 0.20\end{array}$ \\
\hline \multirow[t]{2}{*}{$\begin{array}{l}\mathrm{C}_{\mathrm{Osm}} \\
\mathrm{ml} \cdot \mathrm{min}^{-1}\end{array}$} & - & - & - & - & $\begin{array}{l}1.06 \\
\pm 0.33\end{array}$ & $\begin{array}{l}1.58 \\
\pm 0.68\end{array}$ & $\begin{array}{l}2.37 \\
\pm 0.96\end{array}$ & $\begin{array}{l}1.20 \\
\pm 0.18\end{array}$ \\
\hline & $T_{\beta}$ & $T_{9}$ & $T_{10}$ & $T_{n}$ & $T_{12}$ & $T_{13}$ & $T_{J_{4}}$ & $T_{15}$ \\
\hline \multicolumn{9}{|c|}{ Fentanyl $(n=7)$} \\
\hline $\begin{array}{l}\text { AVP } \\
\mathrm{pg} \cdot \mathrm{ml}^{-1}\end{array}$ & $\begin{array}{l}8.3 \\
\pm 2.7\end{array}$ & $\begin{array}{l}13.0^{*} \\
\pm 1.9\end{array}$ & $\begin{array}{l}8.9 \\
\pm 1.9\end{array}$ & $\begin{array}{l}7.4 \\
\pm 0.6\end{array}$ & $\begin{array}{l}6.8 \\
\pm 0.8\end{array}$ & $\begin{array}{l}4.1 \\
\pm 0.8\end{array}$ & $\begin{array}{l}4.0 \\
\pm 1.6\end{array}$ & $\begin{array}{l}4.6 \\
\pm 0.5\end{array}$ \\
\hline $\begin{array}{l}\mathrm{CH}_{2} \mathrm{O} \\
\mathrm{ml} \cdot \mathrm{min}^{-1}\end{array}$ & $\begin{array}{l}2.53 \\
\pm 1.81\end{array}$ & $\begin{array}{l}-1.21 \\
\pm 0.21\end{array}$ & $\begin{array}{l}-0.80 \\
\pm 0.55\end{array}$ & $\begin{array}{l}-0.80 \\
\pm 0.81\end{array}$ & $\begin{array}{l}-0.38 \\
\pm 0.49\end{array}$ & $\begin{array}{l}-0.30 \\
\pm 0.32\end{array}$ & $\begin{array}{l}-0.06 \\
\pm 0.67\end{array}$ & $\begin{array}{l}-0.6 \\
\pm 0.6\end{array}$ \\
\hline $\mathrm{C}_{\mathrm{Osm}}$ & $\begin{array}{l}6.00 \\
\pm 4.6\end{array}$ & $\begin{array}{l}7.79 \\
\pm 2.46\end{array}$ & $\begin{array}{l}6.39 \\
\pm 1.79\end{array}$ & $\begin{array}{l}9.57 \\
\pm 2.70\end{array}$ & $\begin{array}{l}4.31 \\
\pm 1.16\end{array}$ & $\begin{array}{l}3.96 \\
\pm 1.31\end{array}$ & $\begin{array}{l}4.75 \\
\pm 1.06\end{array}$ & $\begin{array}{l}4.96 \\
\pm 0.8\end{array}$ \\
\hline \multicolumn{9}{|c|}{ Sufentanil $(n=7)$} \\
\hline $\begin{array}{l}\text { AVP } \\
\mathrm{pg} \cdot \min ^{-1}\end{array}$ & $\begin{array}{l}4.6 \\
\pm 1.2\end{array}$ & $\begin{array}{l}7.0 \\
\pm 1.9\end{array}$ & $\begin{array}{l}5.7 \\
\pm 1.1\end{array}$ & $\begin{array}{l}4.9 \\
\pm 0.8\end{array}$ & $\begin{array}{l}9.5 \\
\pm 3.2\end{array}$ & $\begin{array}{l}8.1 \\
\pm 4.1\end{array}$ & $\begin{array}{l}18.0^{*} \\
\pm 6.8\end{array}$ & $\begin{array}{l}10.6 \\
\pm 4.2\end{array}$ \\
\hline $\begin{array}{l}\mathrm{CH}_{2} \mathrm{O} \\
\mathrm{ml} \cdot \mathrm{min}^{-1}\end{array}$ & $\begin{array}{l}-0.03 \\
\pm 0.36\end{array}$ & $\begin{array}{l}-0.36 \\
\pm 0.45\end{array}$ & $\begin{array}{l}-0.33 \\
\pm 0.65\end{array}$ & $\begin{array}{l}-0.17 \\
\pm 0.57\end{array}$ & $\begin{array}{l}-0.22 \\
\pm 0.31\end{array}$ & $\begin{array}{l}-0.71 \\
\pm 0.58\end{array}$ & $\begin{array}{l}-0.06 \\
\pm 0.63\end{array}$ & $\begin{array}{l}-0.3 \\
\pm 0.7\end{array}$ \\
\hline 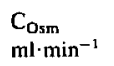 & $\begin{array}{l}1.28 \\
\pm 0.39\end{array}$ & $\begin{array}{l}3.22 \\
\pm 0.75\end{array}$ & $\begin{array}{l}4.19 \\
\pm 1.01\end{array}$ & $\begin{array}{l}3.86 \\
\pm 0.73\end{array}$ & $\begin{array}{l}2.94 \\
\pm 0.68\end{array}$ & $\begin{array}{l}14.40 \\
\pm 4.64\end{array}$ & $\begin{array}{l}9.05 \\
\pm 2.06\end{array}$ & $\begin{array}{l}6.78 \\
\pm 1.9\end{array}$ \\
\hline
\end{tabular}

${ }^{*} p<0.05$. Mean error shown below mean values.

"complete anaesthetic" was stimulated by the observation of Lowenstein et al. ${ }^{6}$ in 1969 that $1 \mathrm{mg}$. $\mathrm{kg}^{-1}$ of morphine in a dose of $1.0 \mathrm{mg} \cdot \mathrm{kg}^{-1}$ produced minimal alterations in cardiovascular haemodynamics in patients with aortic valve disease. Morphine in $1-3 \mathrm{mg} \cdot \mathrm{kg}^{-1}$ doses is associated with problems including hypotension, ${ }^{7.8}$ hypertension, ${ }^{9}$ cardiovascular depression when nitrous oxide is added, ${ }^{10}$ increased blood and fluid requirements ${ }^{11}$ and awareness. ${ }^{12}$

Anaesthesia with fentanyl $50-100 \mu \mathrm{g} \cdot \mathrm{kg}^{-1}$ was proposed by Stanley et al. as an improvement over morphine, providing greater cardiovascular stabil- ity. ${ }^{12,13}$ Fentanyl also suppresses the hormonal response to induction and surgery, although not to cardiopulmonary bypass. ${ }^{14-16}$ Not everyone has been able to reproduce these results while the most common cardiovascular disturbance with high dose fentanyl anaesthesia is hypertension after sternotomy with a reported incidence of 0 to 100 per cent. ${ }^{12,17,18}$ Several cases of intraoperative awareness have also been reported. These problems have led to the use of higher doses of fentany) ${ }^{32}$ (up to $150 \mu \mathrm{g} \cdot \mathrm{kg}^{-1}$ ) with the possible attendant increase in postoperative respiratory depression.

It has been suggested that the more potent an 
opiate analgesic is, the less will be the incidence of side-effects and the greater the cardiovascular stability. ${ }^{21}$ If this is so, then sufentanil should represent an improvement over fentanyl. Initial studies comparing sufentanil and fentanyl for coronary artery bypass surgery tended to support this, with sufentanil giving a reduced incidence of hypertension and tachycardia and being more effective in controlling it when it did occur. ${ }^{22,24}$ However, three recent reports found no difference in the incidence of hypertension between fentanyl and sufentanil even with sufentanil dosages up to $30 \mu \mathrm{g} \cdot \mathrm{kg}^{-1}$. $24-26$

In our study, the incidence of "breakthrough hypertension" following intubation, post-skin incision and/or post-sternotomy was high in both patient groups.

While there was no difference between the fentanyl and sufentanil groups, in the sufentanil group the hypertension responded well to treatment with additional sufentanil. In contrast patients in the fentanyl group required vasodilator therapy in most (five of seven) cases. A recent report claims success in avoiding hypertension by using a rapid sequence induction technique (fentanyl $50 \mu \mathrm{g} \cdot \mathrm{kg}^{-1}$ over 20 seconds); however, no data on haemodynamic responses to sternotomy or cardiopulmonary bypass are given. $^{31}$

Arginine vasopression (AVP) is considered one of the body's stress-responding hormones. ${ }^{14,29}$ Concentrations of AVP in plasma have been reported to increase during anaesthesia and surgery. ${ }^{27}$ Fentanyl has been shown to block the AVP elevation prior to, but not during, cardiopulmonary bypass. ${ }^{14,30}$ Increases in AVP were also seen in patients anaesthetized with halothane and morphine. ${ }^{28}$ The increase in plasma AVP during cardiopulmonary bypass was reported by deLange $e t$ al. to be abolished with alfentanil and with sufentanil. ${ }^{29}$

This study shows that cessation of bypass is associated with AVP levels which increase transiently with sufentanil and decrease with fentanyl. These findings could be ascribed to the shorter duration of sufentanil and the ability of fentanyl to redistribute in body compartments. The report of DeLange et al. supports the inability of fentanyl to suppress bypass AVP secretion regardless of doses used. DeLange et al. also report sufentanil provides continued suppression of AVP throughout bypass and the postoperative period in contrast to our

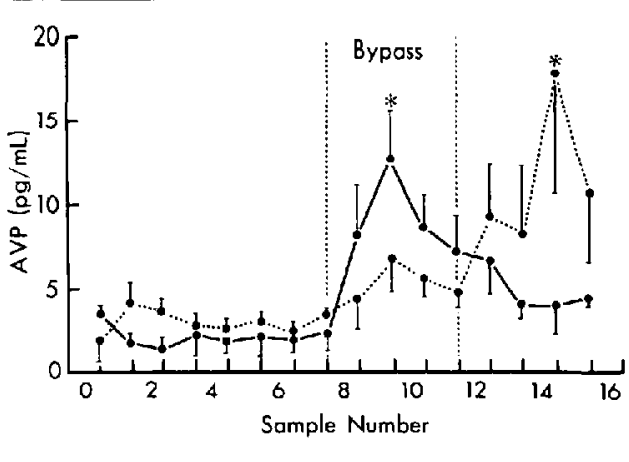

FIGURE Plasma arginine vasopression (AVP) during aortocoronary bypass surgery (mean $\pm \mathrm{SE}$ ). — Fentanyl $(\mathrm{N}=7) ;-\cdots-$ Sufentanil $(\mathrm{N}=7)$.

observation of an increase in AVP prior to the end of surgery. DeLange has further data, as yet unpublished, suggesting the stress response as reflected by plasma levels of catecholamines, may not be suppressed by sufentanil. Such data would support an increased level of AVP as a trend indicator of the stress response but not a transient increase. More importantly, the more frequent sampling intervals used in our study may have revealed a previously unsuspected transient increase in AVP levels.

Plasma concentrations of AVP in patients treated with fentanyl in our study were within the normal range following induction, skin incision and sternotomy, but were found to be elevated during the bypass period (Figure). AVP concentrations returned to basal levels in the post-bypass period. These data are in agreement with those of our previous study ${ }^{30}$ in which plasma AVP concentrations were compared during high-dose fentanyl and halothane anaesthesia. The elevations of AVP during bypass seen in both of our studies were modest (to $7-18 \mathrm{pg} \cdot \mathrm{ml}^{-1}$ ) and were thus not likely to adversely affect peripheral vascular resistance in those patients. The high AVP levels observed by Stanley et al. ${ }^{14}$ have not been recorded in either of our patient series.

In summary, no differences were detected between the two anaesthetic regimens with respect to cardiovasuclar variables, serum osmolality, electrolyte concentrations, haematocrit, plasma protein concentrations, and free water clearance. Modest transient increases in plasma AVP seen during the bypass period in the fentanyl patients were attenu- 
ated in the sufentanil group. However, in the post-bypass period the sufentanil patients exhibited an "escape" from this attenuation, and AVP concentrations in plasma increased. A similar incidence of hypertensive episodes was observed in both groups of patients, but the sufentanil group required less frequent use of vasodilators. However, on the basis of our experience, neither fentanyl in doses of $128 \pm 8.7 \mu \mathrm{g} \cdot \mathrm{kg}^{-1}$ nor sufentanil in doses of $23 \pm 1.4 \mu \mathrm{g} \cdot \mathrm{kg}^{-1}$ can be used as sole agents for anaesthesia in coronary artery bypass patients.

\section{Acknowledgement}

The financial assistance and supply of sufentanil by Janssen Pharmaceutica is gratefully acknowledged.

\section{References}

1 Van Bever WFM, Niemegeers CJE, Schellekens $K H L$, Janssen PAJ. N-4-substituted 1-(2-arylethyl)4-piperidinyl-N-phenyl-propanamides. A novel series of extremely potent analgesics with unusually high safety margins. Arzneim Forsch 1976; 26: 1548-51.

2 Niewegeers CJE, Schellenkens KHL, Van Bever WFM, Janssen PAJ. Sufentanil, a very potent and extremely safe morphine-like compound in mice, rats and dogs. Arzneim Forsch 1976; 26: 1551-6.

3 Bovill JG, Sebel PS, Blackburn CL, Oei-Lin V, Heykants $J J$. The pharmacokinetics of sufentanil in surgical patients. Anesthesiology 1984; 61: 502-6.

4 De Lange S, Boscoe MJ, Stanley TH et al. Comparison of sufentanil $\mathrm{O}_{2}$ and fentanyl $\mathrm{O}_{2}$ for coronary artery surgery. Anesthesiology 1982; 56: 112-8.

5 Ledsome JR, Wilson N, Ngsee J. Time course rate of changes in plasma vasopressin during atrial distention. Can J Physiol Pharmacol 1982; 60: 1210-8.

6 Lowenstein E, Hallowell P, Levine FH, Dagget WN, Austen WG, Laver MG. Cardiovascular responses to large doses of intravenous morphine in man. $\mathrm{N}$ Engl J Med 1969; 281: 1389-93.

7 Lowenstein E. Morphine anesthesia: a perspective. Anesthesiology 1971; 35: 563-5.

8 Arens $J F$, Benbow BP, Oschner $J L$, Theard $R$. Morphine anesthesia for aortocoronary bypass procedures. Anesth Analg 1972; 51: 901-9.

9 Kistner JR, Miller ED, Lake CL, Ross WT. Indices of myocardial oxygenation during coronary artery revascularization in man with morphine versus halothane anesthesia. Anesthesiology 1979; 50: 324-30.

10 McDermot $R W$, Stanley $T H$. The cardiovascular effects of low concentrations of nitrous oxide during morphine anesthesia. Anesthesiology 1974; 41: 89-91.

11 Stanley TH, Gray NH, Stanford W, Armstrong $R$. The effects of high dose morphine on fluid and blood requirements in open heart operations. Anesthesiology 1973; 38: 536-41.

12 Stanley $T H$, Webster $L R$. Anesthetic requirements and cardiovascular effects of fentanyl-oxygen and fentanyl-diazepam-oxygen anesthesia in man. Anesth Analg 1978; 57: 411-26.

13 Lunn JK, Stanley TH, Eisele J, Webster L, Woodward A. High dose fentanyl anesthesia for coronary artery surgery: plasma fentanyl concentrations and influence of nitrous oxide on cardiovascular responses. Anesth Analg 1979; 58: 390-5.

14 Stanley TH, Philbin DM, Coggins CH. Fentanyl oxygen anaesthesia for coronary artery surgery. Cardiovascular and antidiuretic hormone responses. Can Anaesth Soc J 1979; 26: 168-72.

15 Stanley $T H$, Berman L, Green O, Robertson D. Plasma catecholamines and cortisol responses to fentanyl anesthesia for coronary artery operations. Anesthesiology 1980; 53: 250-3.

16 Sever PS, Bovill JG, Schellekens APM, Hawker CD. Hormonal responses to high dose fentanyl anaesthesia. Br J Anaesth 1981; 53: 941-8.

17 Waller JL, Hug Jr CC, Nagle DM et al. Hemodynamic changes during fentanyl oxygen anesthesia for aorto-coronary bypass operation. Anesthesiology 1981; 55: 212-7.

18 Edde RR. Hemodynamic changes prior to and after sternotomy in patients anesthetized with high dose fentanyl. Anesthesiology 1981; 55: 444-6.

19 Mummaneni $N$, Rao TLK, Montoya A. Awareness and recall with high dose fentanyl oxygen anesthesia. Anesth Analg 1980; 59: 948-9.

20 Hilgenberg JC. Intraoperative awareness during high dose fentanyl-oxygen anesthesia. Anesthesiology 1981; 54: 341-3.

21 De Castro J, Van de Water A, Wouters L, Xhonneux $R$, Renaman $R$, Kay $B$. Comparative study of cardiovascular, neurological and metabolic sideeffects of eight narcotics in dogs. Acta Anaesthesiol Belg 1979; 30: 5-99. 
22 Sebel PS, Bovil JG. Cardiovascular effects of sufentanil anesthesia, Anesth Analg 1982; 61: 115-9.

23 Griesemer RW, Moldenhauer CC, Hug Jr CC et al. Sufentanil anesthesia for aorto-coronary bypass surgery $30 \mu \mathrm{g} / \mathrm{kg}$ vs $15 \mu \mathrm{g} / \mathrm{kg}$. Anesthesiology 1982; 57: A48.

24 Howie WB, Lingam RP, Lee JJ et al. Sufentaniloxygen compared with fentanyl-oxygen anesthesia to coronary artery surgery. Anesthesiology 1982; 57: A292.

25 Rosow CE, Philbin DM, Moss J, Keegan CR, Schneider RC. Sufentanil vs fentanyl. Suppression of hemodynamic responses. Anesthesiology 1983; 59: A323.

26 Sebel PS, Bovill JG et al. Electroencephalographic effects of sufentanil anaesthesia in man. $\mathrm{Br} \mathbf{J}$ Anaesth 1982; 54: 45.

27 Suppression of stress responses. Royal Society of Medicine. International Congress and Symposium Series No. 3. London Academic Press 1978; 2-98.

28 Philbin DM, Coggins CH. Plasma antidiuretic hormone levels in cardiac surgical patients during morphine and halothane anesthesia. Anesthesiology 1978; 49: 95-8.

29 DeLange S, Boscoe MJ, Stanley TH, DeBruijn N, Philbin DM, Coggins CH. Antidiuretic hormone and growth hormone responses during coronary artery surgery with sufentanil-oxygen and alfentaniloxygen anesthesia in man. Ancsth Analg 1982; 61: 434 .

30 Crone LA, Wilson N, Ngsee J, Turnbull KW, Leighton $K$. Haemodynamic and plasma vasopressin responses with high dose fentanyl anaesthesia during aorto-coronary bypass operations. Can Anaesth Soc J 1982; 29: 525-31.

31 Murkin JM, Moldenhauer CC, Hug Jr CC. Highdose fentanyl for rapid induction of anaesthesia in patients with coronary artery disease. Can Anaesth Soc J 1985; 32: 320-4.

32 Walsh ES, Patterson JL, O'Riordan JBA, Hall GM Effect of high dose fentanyl anaesthesia on the metabolic and endocrine responses to cardiac surgery. Br J Anaesth 1981; 53: 1155-6.

\section{Résumé}

Cette étude a comparé les réponses hémodynamiques ainsi que l'arginine vasopressin chez les patients ayant reçu du fentanyl ou du sufentanit lors d'une chirurgie pour pontage aorto-coronarien. Quatorze patients normotendus avec une bonne fonction ventriculaire gauche ont été étudiés. Les patients ont été induits avec du fentanyl $(N=7) 37.5 \mu \mathrm{g} \cdot \mathrm{kg}^{-1}$ ou du sufentanil $(N=7)$ $7.5 \mu \mathrm{g} \cdot \mathrm{kg}^{-1}$ en perfusion intraveineuse pour trois minutes. Ni une rigidité thoracique significative $n i$ une bradycardie ou un rappel des événements peropératoires $n$ ' est survenues. Tous les patients ayant reçu du fentanyl ont présenté une hypertension après l'induction et cinq ont requis une thérapie au vasodilateur car ils n'ont pas répondu au bolus de fentanyl $\left(12.5 \mu \mathrm{g}^{\cdot} \mathrm{kg}^{-1}\right)$. Deux de ces cinq patients a démontré une dépression significative du segment ST (plus grand que $1 \mathrm{~mm}$ ). Cinq patients du groupe sufentanil ont présenté une hypertension après l'induction. Quatre de ces patients ont répondu à des doses additionnelles de sufentanil ( $3.75 \mu \mathrm{g} \cdot \mathrm{kg}^{-1}$ ) alors qu'un seul a requis une thérapie aux vasodilateurs suite à une dépression concomitante du segment $S T$. Le sufentanil a atténué l'augmentation de l'arginine vasopressin lors de la CEC. Les niveaux d'arginine vasopressin pour le groupe fentanyl étaient significativement plus haute que ceux du groupe sufentanil lors de la CEC. Les niveaux de AVP après CEC étaient supérieurs chez les patients du groupe sufentanil.

L'incidence d'hypertension était similaire dans les deux groupes. L'hypertension était plus facilement traitée pour le groupe sufentanil et l'administration concomitante de vasodilateurs (nitroglycérine) érait re. quise dans les deux groupes de patients hypertendus. Ni le fentanyl à des doses de $128 \pm 8.7 \mu \mathrm{g} \cdot \mathrm{kg}^{-1}$ ni le sufentanil à des doses de $23 \pm 1.4 \mu \mathrm{g} \cdot \mathrm{kg}^{-1}$ peut être l'agent anesthésique unique chez les adultes avec une bonne fonction ventriculaire quand le temps d'induction est de trois minutes et des bolus de rajout sont utilisés. 